\title{
The Ascitic Fluid Fibronectin Level to Differentiate Malignant From Nonmalignant Ascites
}

Dr. Mohammad Nurul Islam Khan ${ }^{1 *}$, Dr. Nooruddin Ahmad², Dr. Md. Abdul Kader Zilani ${ }^{3}$, Dr. Priobrata Karmakar ${ }^{4}$, Dr Sushanta Kumar Barman ${ }^{5}$, Dr. Md. Mostofa Alam ${ }^{6}$

${ }^{1}$ Assistant Registrar, Department of Medicine, Rangpur Medical College Hospital, Rangpur, Bangladesh

${ }^{2}$ Professor, Department of Hepatology, BSMMU, Dhaka, Bangladesh

${ }^{3}$ Assistant Professor, Department of Hematology, Rangpur Medical College, Rangpur, Bangladesh

${ }^{4}$ Assistant Professor, Department of Medicine, Rangpur Medical College, Rangpur, Bangladesh

${ }^{5}$ Registrar, Department of Medicine, Rangpur Medical College Hospital, Rangpur, Bangladesh

${ }^{6}$ Assistant Registrar, Department of Medicine, Rangpur Medical College Hospital, Rangpur, Bangladesh

DOI: $10.36347 /$ sjams.2020.v08i07.003

| Received: 19.06.2020 | Accepted: 26.06.2020 | Published: 04.07.2020

*Corresponding author: Dr. Mohammad Nurul Islam Khan

Abstract

Original Research Article

Objective: In this study our main goal is to evaluate the ascitic fluid fibronectin level to differentiate malignant from nonmalignant ascites. Method: This observational, cross sectional type study conducted in Department of Hepatology, Bangabandhu Sheikh Mujib Medical University, Dhaka from September 2014 to February 2017. During the study period of total 60 patients (30 patients with malignant ascites and 30 patients with nonmalignant ascites) were enrolled for the study. Results: Mean ascetic fluid fibronectin was found $0.50 \pm 0.15 \mu \mathrm{g} / \mathrm{ml}$ in malignant ascites group and $0.22 \pm 0.07 \mu \mathrm{g} / \mathrm{ml}$ in nonmalignant ascites group. Mean ascitic fluid fibronectin was found $0.64 \pm 0.11 \mu \mathrm{g} / \mathrm{ml}$ in positive for malignant cell group and $0.45 \pm 0.17 \mu \mathrm{g} / \mathrm{ml}$ in negative for malignant cell group. The mean difference was not statistically significant ( $>0.05$ ) between two groups. Sensitivity of cut off value of ascitic fluid fibronectin $\geq 0.22$ $\mu \mathrm{g} / \mathrm{ml}$ was $82.86 \%$, specificity $96.0 \%$, accuracy $88.33 \%$, positive and negative predictive values were $96.67 \%$ and $80.0 \%$ respectively. Conclusion: The present study revealed on the usefulness of fibronectin in the differential diagnosis of ascites and these data and findings suggest that fibronectin may have potential value to differentiate malignant from nonmalignant ascites.

Keywords: Ascitic fluid fibronectin, malignant ascites, nonmalignant ascites.

Copyright @ 2020: This is an open-access article distributed under the terms of the Creative Commons Attribution license which permits unrestricted use, distribution, and reproduction in any medium for non-commercial use (NonCommercial, or CC-BY-NC) provided the original author and source are credited.

\section{INTRODUCTION}

Ascites is the pathologic accumulation of fluid in the peritoneal cavity [1]. It forms because of conditions directly involving the peritoneum (malignancy, infection), or diseases remote from the peritoneum (liver disease, heart failure, hypoproteinaemia). Cirrhosis is the commonest cause of ascites $(85 \%)$, remaining $15 \%$ have a cause other than liver disease, including peritoneal tuberculosis, cancer, cardiac failure or nephrotic syndrome [2].

Differentiation between malignant and nonmalignant ascites is a common clinical problem because no single routine biochemical laboratory test can completely distinguish between them and, although cytological examination of ascitic fluid is highly specific, its diagnostic sensitivity is only about $40-60 \%$ $[3,4]$. There are no distinctive features and no single diagnostic test is accurate in differentiating malignant and nonmalignant ascites [5]. There is a chance of false positive results in cytological examination as reactive mesothelial cells in the ascitic fluid are mimic of malignant cells [6]. Various tumor markers (CA 19-9, CEA, AFP, CA 125, CA 15-3) are used to diagnose primary site of malignancy. But these are too sensitive to diagnose. On the other hand, diagnostic performance of these tumor markers in malignant ascites is not conclusive.

In this study our main goal is to evaluate the ascitic fluid fibronectin level to differentiate malignant from nonmalignant ascites.

\section{OBJECTIVE \\ General objective}

- To evaluate the ascitic fluid fibronectin level to differentiate malignant from nonmalignant ascites. 


\section{Specific objective}

- To detect relation of ascitic fluid fibronectin in malignant ascites with negative and positive for malignant cell

- To assess performance of diagnostic test in the patients.

\section{Methodology}

\section{Study type}

- This was an observational, cross sectional type study.

\section{Place and period of the study}

- This study was conducted in Department of Hepatology, Bangabandhu Sheikh Mujib Medical University, and Dhaka from September 2014 to February 2017.

\section{Study Population and sample size}

- During the study period of total 60 patients (30 patients with malignant ascites and 30 patients with nonmalignant ascites) were enrolled for the study.

\section{Study procedure}

- Patients with ultrasonographic evidence ascites admitted in the Department of Hepatology, Oncology, Gynae Oncology and Internal Medicine of BSMMU were provisionally selected. Then proper history, clinical examination and some initial investigations like $\mathrm{CBC}, \mathrm{S}$. Albumin, Urine R/M/E, Ascitic fluid study (Cytology, total protein, SAAG, ADA, malignant cell) and Chest X-ray P/A view were done for matching of inclusion and exclusion criteria. Further investigations were done according to the study protocol like ECG, Echocardiography, AFP, CA 19-9, CEA, CA 125, CA 15-3, TVS, Endoscopy of UGIT, Colonoscopy, CT Scan of abdomen, FNA from primary site, Laparoscopy/ Laparotomy with biopsy. Patients who meet inclusion \& exclusion criteria were informed in details about the study.

\section{Data processing and data analysis}

- The statistical analysis was carried out using the Statistical Package for Social Sciences version 20.0 for Windows (SPSS Inc., Chicago, Illinois, USA). The mean values were calculated for continuous variables. The quantitative observations were indicated by frequencies and percentages. Chi-Square test was used to analyze the categorical variables, shown with cross tabulation. Sensitivity, specificity, positive predictive value and negative predictive value were calculated by using the area under the receiver operating characteristic (AUROC) curves. $\mathrm{P}$ value of $<0.05$ was taken as significant.

\section{RESULTS}

In figure-1 shows age distribution of the patients where in nonmalignant ascites group 9(30.0\%) patients belonged to age 41-50 years and malignant ascites group majority $8(26.7 \%)$ patients belonged to age 51-60 years. The mean age was found 29.19 \pm 9.11 years were nonmalignant group and $32.80 \pm 9.20$ years in malignant group. The following figure is given below in detail:

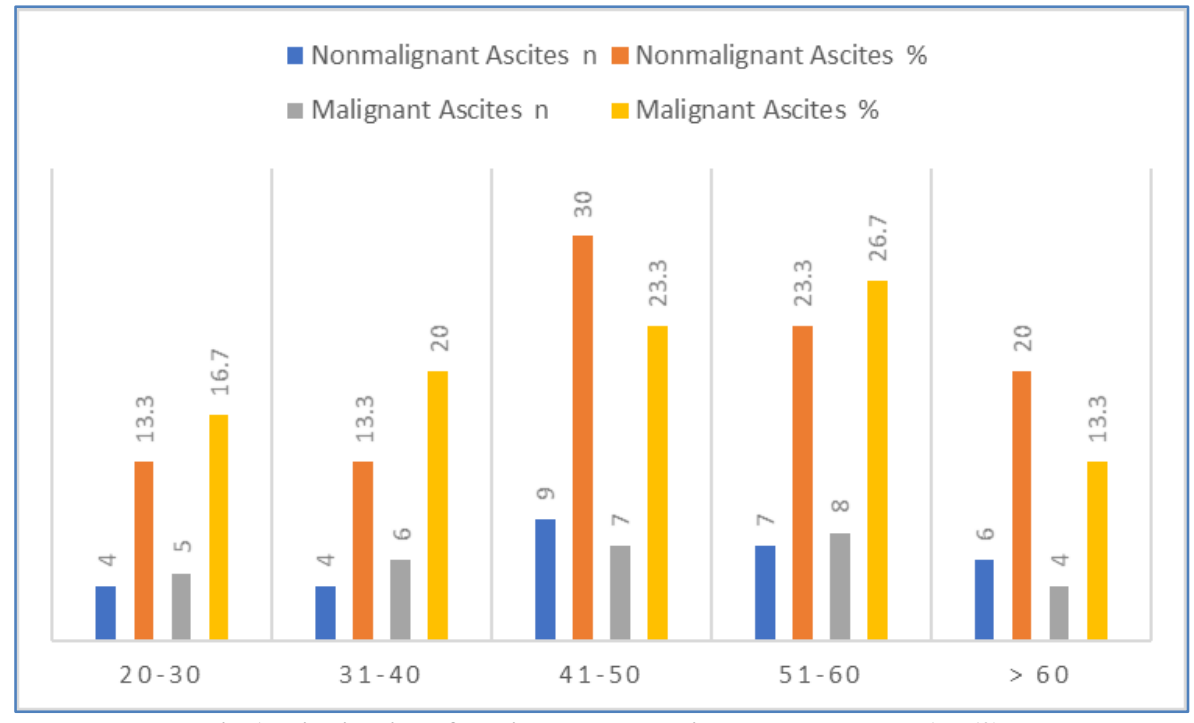

Fig-1: Distribution of age in years according to study groups $(\mathrm{n}=60)$

In figure-2 shows gender distribution of the study patients, it was observed that male was found $22(73.3 \%)$ in nonmalignant ascites group and $13(43.3 \%)$ in malignant ascites group. The difference was statistically significant $(p<0.05)$ between two groups. Female patients were more in malignant group compared to male. The following figure is given below in detail: 


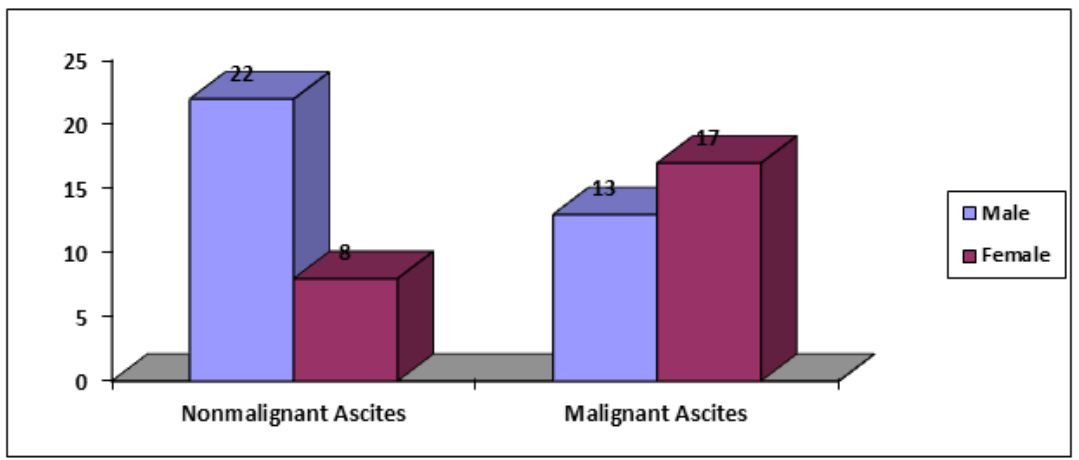

Fig-2: Gender distribution of the study patients

In table-1 shows relation between ascitic fluid fibronectin between malignant and nonmalignant ascites. Mean ascetic fluid fibronectin was found $0.50 \pm 0.15 \mu \mathrm{g} / \mathrm{ml}$ in malignant ascites group and
$0.22 \pm 0.07 \mu \mathrm{g} / \mathrm{ml}$ in nonmalignant ascites group. The mean difference was statistically significant $(\mathrm{p}<0.05)$ between two groups. The following table is given below in detail:

Table-1: Relation between ascitic fluid fibronectin between malignant and nonmalignant ascites $(\mathbf{n}=60)$

\begin{tabular}{|l|l|l|l|}
\hline Variable & Nonmalignant ascites Mean $( \pm$ SD $)$ & $\begin{array}{l}\text { Malignant ascites } \\
\text { Mean }( \pm \text { SD })\end{array}$ & p value \\
\hline Ascitic fluid fibronectin $(\mu \mathrm{g} / \mathrm{ml})$ & $0.22( \pm 0.07)$ & $0.50( \pm 0.15)$ & $<0.001$ \\
\hline
\end{tabular}

In table-2 shows relation of ascitic fluid fibronectin with negative and positive for malignant ascitic cell. Mean ascitic fluid fibronectin was found $0.64 \pm 0.11 \mu \mathrm{g} / \mathrm{ml}$ in positive for malignant cell group and $0.45 \pm 0.17 \mu \mathrm{g} / \mathrm{ml}$ in negative for malignant cell group. The mean difference was not statistically significant $(\mathrm{p}>0.05)$ between two groups. The following table is given below in detail:

Table-2: Relation of ascitic fluid fibronectin in malignant ascites with negative and positive for malignant cell

\begin{tabular}{|l|l|l|l|}
\hline Variable & $\begin{array}{l}\text { Positive for malignant cell } \\
\text { Mean }( \pm \text { SD })\end{array}$ & $\begin{array}{l}\text { Negative for malignant cell } \\
\text { Mean }( \pm \text { SD })\end{array}$ & $\begin{array}{l}\text { p } \\
\text { value }\end{array}$ \\
\hline $\begin{array}{l}\text { Ascitic fluid fibronectin } \\
(\mu \mathrm{g} / \mathrm{ml})\end{array}$ & $0.54( \pm 0.11)$ & $0.45( \pm 0.17)$ & 0.49 \\
\hline
\end{tabular}

In figure-3 shows receiver-operator characteristics (ROC) curve of ascitic fluid fibronectin for performance of diagnostic test. The test result variable(s): Ascitic fluid fibronectin (0.951) has at least one tie between the positive actual state group and the negative actual state group. 95\% Confidence Interval of the difference lower 0.884 and upper 1.0. Ascitic fluid fibronectin $\geq 0.22 \mu \mathrm{g} / \mathrm{ml}$. The following figure is given below in detail:

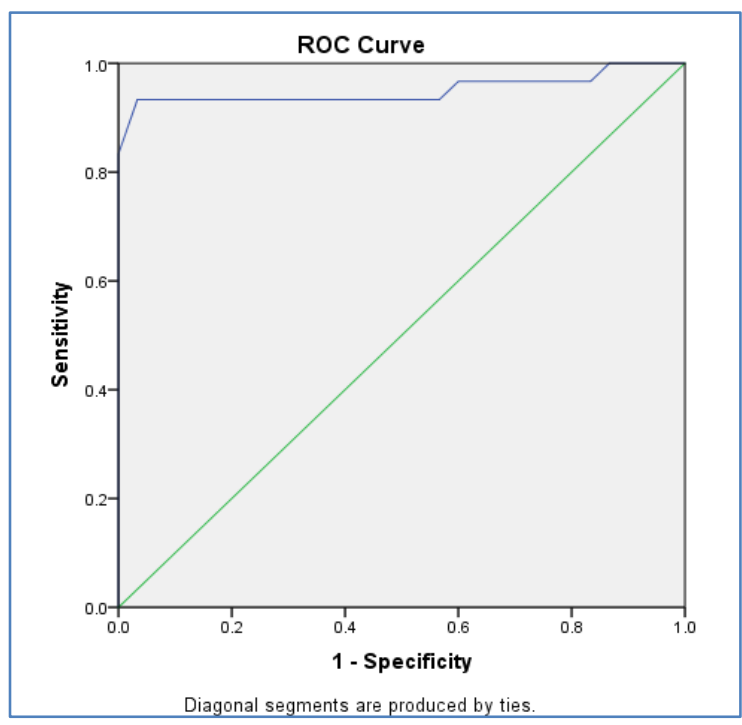

Fig-3: Receiver -operator characteristics (ROC) curve of ascitic fluid fibronectin for performance of diagnostic test 
Nurul Islam Khan et al., Sch J App Med Sci, July, 2020; 8(7): 1651-1655

In table-3 shows performance of diagnostic test where table shows that sensitivity of cut off value of ascitic fluid fibronectin $\geq 0.22 \mu \mathrm{g} / \mathrm{ml}$ was $82.86 \%$, specificity $96.0 \%$, accuracy $88.33 \%$, positive and negative predictive values were $96.67 \%$ and $80.0 \%$ respectively. The following table is given below in detail:

Table-3: Performance of diagnostic test

\begin{tabular}{|l|l|l|l|l|l|}
\hline Variable & Sensitivity & Specificity & PPV & NPV & Accuracy \\
\hline Cut off value of ascitic fluid fibronectin $\geq 0.22 \mu \mathrm{g} / \mathrm{ml}$ & $82.86 \%$ & $96.00 \%$ & $96.67 \%$ & $80.0 \%$ & $88.33 \%$ \\
\hline
\end{tabular}

\section{DISCUSSION}

Regarding gender distribution of the study patients, it was observed that male was found $13(43.3 \%)$ in malignant ascites group and $22(73.3 \%)$ in nonmalignant ascites group. The difference was statistically significant $(\mathrm{p}<0.05)$ between two groups. In our study female patients were more in malignant group. Similar observations were found in different studies. One study showed that $25(33.3 \%)$ were males and $50(66.7 \%)$ females. Male was found 7 in malignant group and 18 in nonmalignant group. Female was 30 in malignant group and 20 in nonmalignant group. ${ }^{6}$ Another report showed 55 was female and 52 were male [7].

In this study the mean ascitic fluid fibronectin was found $0.50 \pm 0.15 \mu \mathrm{g} / \mathrm{ml}$ in malignant ascites group and $0.22 \pm 0.07 \mu \mathrm{g} / \mathrm{ml}$ in nonmalignant ascites group. The mean difference was statistically significant $(p<0.05)$ between two groups. One study showed that the mean ascitic fibronectin concentration in patients with malignant ascites was $97.54 \pm 17.73 \mu \mathrm{g} / \mathrm{ml}$ as against $47.76 \pm 13.32 \mu \mathrm{g} / \mathrm{ml}$ seen in nonmalignant ascites $(\mathrm{p}<0.001)$ [6]. Another study showed that concentrations of ascitic fibronectin were significantly higher in malignant ascites than in nonmalignant ascites. They also showed that there is a link between malignancy and fibronectin levels [8]. Another report showed that the mean values of ascitic fluid fibronectin, for malignant and nonmalignant group were $538 \pm 46$ $\mathrm{pg} / \mathrm{mL}$ and $60 \pm 4.92 \mathrm{pg} / \mathrm{mL}$, respectively $(\mathrm{p}<0.001)$ [9].

In our study showed that sensitivity of cut off value of ascitic fluid fibronectin $\geq 0.22 \mu \mathrm{g} / \mathrm{ml}$ was $82.86 \%$, specificity $96.0 \%$, accuracy $88.33 \%$, positive and negative predictive values were $96.67 \%$ and $80.0 \%$ respectively. One study showed the diagnostic accuracy of fibronectin in ascitic fluid was found to be $94.7 \%$, using a cut-off value of $73 \mu \mathrm{g} / \mathrm{ml}$. The sensitivity, specificity, and accuracy of fibronectin were $94.6 \%$, $94.7 \%$ and $94.7 \%$ respectively [6]. This agrees with earlier studies done by other study who got an accuracy of $97.1 \%$ in their study and a sensitivity of $100 \%$.

Another report also conducted similar studies and arrived at a diagnostic accuracy of $95.9 \%$ for ascitic fibronectin [10]. In a similar study showed $100 \%$ accuracy for fibronectin as against $78.7 \%$ for malignant cytology. This implies that fibronectin may be more sensitive for diagnosis of malignant ascites [11]. The specificity of ascitic fibronectin in this study (94.7\%), is similar to that reported by other studies [13].

\section{CONCLUSION}

The present study revealed on the usefulness of fibronectin in the differential diagnosis of ascites and these data and findings suggest that fibronectin may have potential value to differentiate malignant from nonmalignant ascites.

\section{REFERENCE}

1. Ghilain JM, Henrion J, Schapira M, Majois F, Beauduin M, Heller FR. Ascitic fluid: The value of various biological tests in the differential diagnosis between cirrhotic and neoplastic ascites. Acta gastro-enterologica Belgica. 1990;53(2):168-79.

2. Barry R. Bloom, editor. Tuberculosis: pathogenesis, protection, and control. ASM press; 1994.

3. AKSOY H, KIZILTUNÇ A, AKSOY Y, KURTUL $\mathrm{N}$, BAKAN E. Determination of $\mathrm{pH}$, fibronectin, cholesterol, lactate dehydrogenase and sialic acid in the differentiation of nonmalignant and malignant ascites. Turkish Journal of Medical Sciences. 1998 Oct 20;28(5):549-54.

4. Jha R, Shrestha HG, Sayami G, Pradhan SB. Study of effusion cytology in patients with simultaneous malignancy and ascites. Kathmandu University medical journal (KUMJ). 2006;4(4):483-7.

5. Junaid TA, Odor EI. Cytologic diagnosis of ascitic fluid in Ibadan, Nigeria. Journal of the National Medical Association. 1980 Jul;72(7):669.

6. Karagol BS, Zenciroglu A, Gokce S, Kundak AA, Ipek MS. Therapeutic management of neonatal chylous ascites: report of a case and review of the literature. Acta Paediatrica. 2010 Sep;99(9):130710.

7. Karuri NW, Lin Z, Rye HS, Schwarzbauer JE. Probing the conformation of the fibronectin III1-2 domain by fluorescence resonance energy transfer. Journal of Biological Chemistry. 2009 Feb 6;284(6):3445-52.

8. Mahmood K, Saeedi MI, Mohammad R, Kamal M Percutaneous needle peritoneal biopsy in the diagnosis of exudative ascites. Journal of Ayub Medical College, Abbottabad: JAMC. 2008;20(4):94.

9. Kim NJ, Choo EJ, Kwak YG, Lee SO, Choi SH, Woo JH, Kim YS. Tuberculous peritonitis in cirrhotic patients: comparison of spontaneous 
bacterial peritonitis caused by Escherichia coli with tuberculous peritonitis. Scandinavian journal of infectious diseases. 2009 Jan 1;41(11-12):852-6.

10. Kuiper JJ, Van Buuren HR, De Man RA. Ascites in cirrhosis: a review of management and complications. Neth J Med. 2007 Sep 1;65(8):2838.

11. Lee CM, Changchien CS, Shyu WC, Liaw YF. Serum-ascites albumin concentration gradient and ascites fibronectin in the diagnosis of malignant ascites. Cancer. 1992 Oct 15;70(8):2057-60.

12. Liu F, Kong X, Dou Q, Ye J, Xu D, Shang H, Xu $\mathrm{K}$, Song Y. Evaluation of tumor markers for the differential diagnosis of benign and malignant ascites. Annals of Hepatology. 2014 Jun 30;13(3):357-63. 